\title{
5. 電算機表示とメモリー
}

\section{1. まえがき}

計算機と人間の情報交換の手段として，ディスプレイ 蜆在，各方面で多数利用されるようになった，開発の 初期にはディスプレイといえば,リフレッシュ型の CRT を用いたものを指していたが，近年，蓄積管，PDP，液 搨など, 新しい表示デバイスの開発がなされ，ディスプ レイの種類も非常に多くなってきた.

従来, ディスプレイは表示内容加ら，キャラクターデ ィスプレイとグラフィックディスプレイに分類されて呼 ばれていたが，新しい表示デバイスが出現してから，リ フレッシュ型とストレージ型の分類が生まれた.

本稿では表示情報がメモリーにコードで蓄積されてい るか, 画像に展開された形で蓄積されているかによっ て，ディスプレイをコードメモリー型と画像メモリ一型 に分類し, 乙れらに使用されるメモリ一の種類, 特徽,

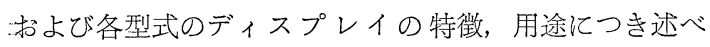
る. また最近, 開発されている表示デバイスの中から, それ自身にメモリ一機能のある蓄積管, PDP, 液晶, 力 ソードクロミック管などにつき紹介する。これらはいず れあ画像メモリ一型のディスプレイに使用されるあので ある。

\section{2. 表示方 式}

現在, ディスプレイに使用されている表示デバイスと しては，それ自体にメモリ一機能を持たないリフレッシ ュ型 CRT が主流をなしている. 近年, Techtronics 社 で直視型蓄積管が開発され，一部のディスプレイに使用 されるようになった ${ }^{122)}$.

リフレッシュ型 CRT を使用する場合, コンピュータ 一から送られてくる表示データを，CRT にちらつくと となく表示するには，同じ表示データを每秒 30〜60 回 の割合で繰返して CRT に送り，表示する(これをリフ

"5. Computer Display and Memory" by Hajime Hayashi (Fujitsu Ltd., Kawasaki)
富士通株式会社 林

治
レッシュと呼ぶ）必要がある．表示データを回線で送る 場合はあちろんのとと, コンピューターにディスプレイ が直結されている場合であ, リフレッシュのために同じ データを繰返して送るととはシステムの效率をきわめて 悪くするため, 通常, ディスプレイにリフレッシュメモリ 一が内蔵されていて, コンピューターから送られてくる 表示データは，いったんリフレッシュメモリーにストア されて，こてから CRT 繰返し送られて表示される.

一方, 直視型蓄皘管を使用する場合には，蓄積管自体 がメモリーと表示の機能を兼亦備えているため, コンピ ユーターからディスプレイへの表示データの転送は一度 だけで良く、リフレッシュの必要はない.

メモリ一機能のない CRT を使用した前者の表式方式 はリフレッシュ方式, 蓄積管を使用した後者の表示方式 はストレージ方式と区別して呼ばれているようである.

しかし最近, プラズマディスプレイパネル (PDP) や 走査変換管を用いたディスプレイが開発され, 前記の表 示形式の分類では不充分と思われる．何故ならばこれら の素子はメモリー機能があり，しかも表示のためにリフ レッシュを必要とするので，乙れらの素子を使用したデ ィスプレイはリフレッシュ方式か，ストレージ方式か区 別ができない.

ここでは，表示情報がメモリーにどのような形でスト アされているかにより，そのディスプレイの適用分野 が，かなり限定されることから，ディスプレイをメモリ 一内の情報形式により分類して述べることにする.

\section{3. コードメモリーと画像メモリー}

表示情報がどのような形でメモリーにストアされてい るかによって，ディスプレイをコードメモリ一型と画像 メモリー型とに大別するととができる.

図1にコードメモリー型のディスプレ゙イの構成を示 す.コードメモリー型の場合には，コンピューターから 送られてくる表示情報は，そのままコードの形でメモリ ーにストアされた後，1語ずつ順次読出され，DA 変換 


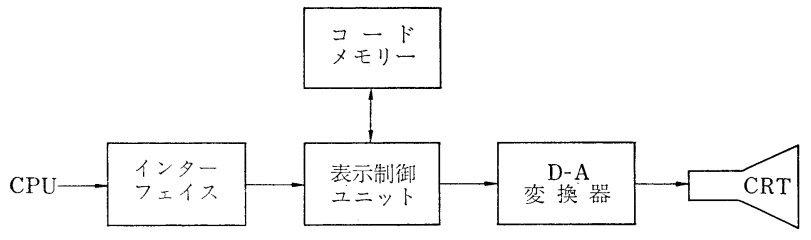

図 1 コードメモリー型ディスプレイ構成図

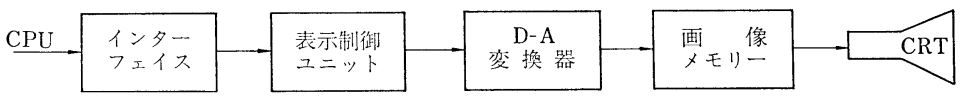

図 2 画像メモリー型ディスプレイ構成図

器でアナログ信号に変換されて CRT に表示される. メ モリーからの表示情報の読取り $\rightarrow \mathrm{DA}$ 変換 $\rightarrow \mathrm{CRT}$ 表示 の動作が毎秒数十回繰返して行なわれる.

通常, DA 変換器の部分に, 文字発生器やベクトル発 生器を有しており，文字表示する位置とその文字コード を指定すれば，文字発生器により文字を形成するに必要 な一連の輝点あるいはベクトルを発生して文字を表示す る. ベクトルを表示する場合にはベクトルの始点と終点 を指定するだけで，所定の位置にベクトルが表示される

\begin{tabular}{|l|c|c|}
\hline POSITION & $X_{1}$ & $Y_{1}$ \\
\hline VECTOR & $\Delta X_{1}$ & $\Delta Y_{1}$ \\
\hline VECTOR & $\Delta X_{2}$ & $\Delta Y_{2}$ \\
\hline VECTOR & $\Delta X_{3}$ & $\Delta Y_{3}$ \\
\hline POSITION & $X_{2}$ & $Y_{2}$ \\
\hline CHARACTER & \multicolumn{2}{|c|}{ F } \\
\hline CHARACTER & \multicolumn{2}{|c|}{ U } \\
\hline CHARACTER & \multicolumn{2}{|c|}{ I } \\
\hline CHARACTER & \multicolumn{2}{|c|}{ ADDRESS } \\
\hline JUMP &
\end{tabular}

図 3 コードメモリーの内容の一例

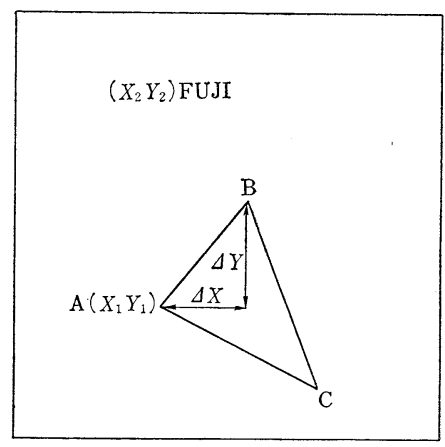

図 4 表 示 例
ようになっている.

コードメモリーでストアされている表示情報の一例を 図3に示す. この例は図 4 亿示す図形, 文字を表示する あので, まず座標点 $\left(X_{1}, Y_{1}\right)$ にビームを移動させてお き, ベクトル $\mathrm{AB}, \mathrm{BC}, \mathrm{CA}$ の長さをビームの移動量 $\Delta X, \Delta Y$ で指定し, 次に文字 $\mathrm{F}$ の座標点 $\left(X_{2}, Y_{2}\right)$ に ビームを移動し，その点から FUJI の文字を表示する. 最後の JUMP 命令で, 先頭のメモリーアドレスを指定: し，繰返して読出し，表示を行なうあのである.

図 2 に画像メモリ一型のディスプレイの構成を示す. 画像メモリ一の場合には，コンピューターから送られて くる表示情報はただちに DA 変換された後に，画面に 表示される画像とまったく同じ形でメモリーされる.

たとえば直視型蓄積管の場合には，表示画像と同じ形 の電荷像が CRT 面に蓄積されていて, てれが螢光膜に 当る電子流の強さを制御するととにより, 可視像を得て いる.

ディスク，IC，コアなどのメモリーを画像メモリーと して用いる場合には，画面をたとえば $X$ 軸， $Y$ 軸方向 に $512 \times 512$ ，あるいは $1024 \times 1024$ の画素に分解し，乙 れらの画素を単位にしてメモリーにストアされる. 1 画 素に対し, 白黒 2 階調の場合には 1 ビット, カラー 7 色. ならば 3 ビットのメモリーが割り当てられる.メモリー からの読出しは, ディスク, IC, コア, いずれの場合に も, ビットシリアルに読出されて，ラスタースキャン方 式で CRT に表示される.

PDP の場合にも画素単位にメモリーされるが，との 場合はメモリーと表示の機能をともに有しているので, メモリー内容がそのまま PDP に表示される.

蓄積型走査変換管 (SCT) の場合には, SCT のメモリ ーターゲットに画像情報がアナログ的に蓄積されてお り，てれをラスタースキャン方式で読取り，表示用の CRT に表示する.

いずれにしても，画像メモリ一型のディスプレイてで は,メモリー内容は表示画面内のある座標点の画素につ 


\section{5. 電算機表示とメモリー}

いての情報のみを表わすが，それが文字なのかベクトル の一部なのかについては，何ら意味を持たない．乙れに 対し、コードメモリーの場合には, メモリー内容の単位 が，画面上の位置，文字，ベクトルなどになっている.

\section{4. メモリ一の種類と特徵}

ディスプレイに使用されるメモリーとしては表 1 のよ うなあのがある.

\section{1 コードメモリー}

コードメモリーにはディレイライン，コア，ICなど のメモリーがある.ディスプレイが開発された初期に は，ディレイラインメモリーが多く使用されたが，最 近では ICメモリーの価格が非常に安くなり，小型で信 頼性があり，所要電源電圧が低いととなどの理由によ り，ICメモリーがディスプレイに使用されるようにな った. ICメモリーにはランダムアクセス型 (RAM) と シフトレジスターとがある.

ディスプレイには文字あるいは特殊記号のみしか表示 できないキャラクターディスプレイとキャラクターの他 に任意の図形を表示できるグラフィックディスプレイと があるが，キャラクターディスプレイの場合には，1画 面に表示できる文字数や文字を表示する位置が決められ ており，メモリー容量として 1 画面分のものが内蔵され ており,メモリーの読出しはまったくシーケンシャルに 行なわれる，そのためキャラクターディスプレイの場合 には価格の安いシフトレジスターが多く利用されてい る.

グラフィックディスプレイの場合に，特殊なシンボル を何力所にあ表示するようなとき，たとえば回路図の中 のトランジスタ, 抵抗器, コンデンサなどを表示すると き，乙れらのシンボルをサブピクチャーとしてメモリー の一部にストアしておき, 何度もこのメモリー内容を利 用してシンボルを表示するようにすれば，全体のメモリ 一容量は少なくてすむため, グラフィックディスプレイ の場合には RAM が多く用いられている.

趇 1 メモリ一素子の種類と用途

\begin{tabular}{|c|c|c|}
\hline メモリ一形式 & メモリ一素子 & 表 示 方 式 \\
\hline コードメモリー & $\begin{array}{l}\text { ディレイライン } \\
\text { コ } \\
\mathrm{I}\end{array}$ & ランダムスキャン \\
\hline \multirow{3}{*}{ 画像メモリー } & $\begin{array}{lr}\text { ディス ク } \\
\mathrm{I} & \mathrm{C} \\
\text { 走查変換管 }\end{array}$ & ラスタースキャン \\
\hline & $\begin{array}{lll}\mathrm{P} & \mathrm{D} & \mathrm{P}\end{array}$ & 全面同時スキャン \\
\hline & $\begin{array}{l}\text { 直視型蓄積管 } \\
\text { 液 } \quad \text { 晶 } \\
\text { カソードクロミック }\end{array}$ & 連 続 発 光 \\
\hline
\end{tabular}

\section{2 画像メモリー}

画像メモりーとしてはディスク, IC, 走査変換管, 直 視型蓄積管, PDP, 液晶, カソードクロミック管などが ある。

ディスクは高価であるが，画像メモリーの場合には， 1 画面を構成する画素数が多く，特にカラー表示や多階 調の表示を行なう場合はメモリ一容量を多く必要とする ため, よく使用されている. IC メモリーは 1 画面の画 素数が $256 \times 256$ ，または $512 \times 512$ 程度の粗い画像を表 示する場合には使用されているが，乙れ以上の精細な表 示に対しては，メモリーコストが現在では高く実用的 ではない，画面がオペレーターから離れている場合は $256 \times 256$ 程度の画素数であ充分な場合があるが，画面 がオペレーターの手が届く程度に近接して置かれている 場合, 直線や曲線をなめらかに表示するには少なくとも $1024 \times 1024$ 程度の画素数が必要と思われる。

走查変換管は直径 1〜1.5 in のメモリーターゲットに アナログ的に画像を書込み，乙れをラスタースキャン方 式で読取り，別の CRT に表示するあのである. ラスタ 一数を 1000 本くらいにすれば，ほぼ満足できる画質を 得ることができる. 画像のメモリ一時間に制限がある が，10 分間程度はほとんど画質に変化がみられないの で，人間とコンピューターとの会話の手段としてのディ スプレイとしては充分であると思われる. 走査変換管は メモリーとしてのみ機能し，表示は別の CRTで行なう ので，表示画面の大きさを任意にとることができ，輝度 も充分高くできる利点がある．ただアナログデバイスで あるので，周辺回路がやや複雑になる欠点がある.

直視型蓄積管は表示用の CRT にメモリー機能を有し ているため, CRT 周辺回路は簡単になるが，輝度が低 く明るい部屋では見にくい欠点がある。また，部分消去 ができないので，一部の図形を書き変えるにも全面消去 をしなければならない欠点がある. 分解能は良く, 多量 の情報をちらつきなく表示することが可能である.

PDP はパネル自体にメモリー機能を有しており, 画 面が平坦, 表示精度が良い, 輝度が高いなど, 多くの長所 を有している. 現在, in 当り 60 本の分解能で, 8 in $\times$ 8 in の大きさのパネルが Owens Ilinoi 社で開発されて いる. PDP は蓄積管と違って画面の位置指定はディジ タル的に行なうので, 駆動回路の基本回路は簡単である が，数量が多くなるので，これをいかに簡単化できるか が問題となっている.

以上の他，液晶やカソードクロミズムを利用した，メ モリ一機能のある表示デバイスの開発がなされている. これらについては後述する。 


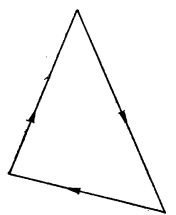

(a) ランダムスキャン

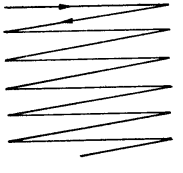

(b) ラスタースキャン

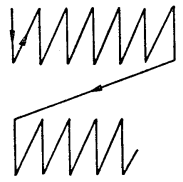

(c) モデイファイト

図 5 スキャン方式

\section{5. 表示方 法}

表示画面に文字や図形を表示する方法には，その画面 からの発光の仕方から次の 5 種類のものがある.

(1) ランダムスキャン

(2) ラスタースキャン

(3) モディファイドラスタースキャン

(4) 全面同時スキャン

(5) 連続発光

上記(1)，(2)，(3)のスャン方式はリフレッシュ型で CRT の表示に用いられている. 図 5 (a) に示すように ランダムスキャンでは電子ビームの移動には規則性がな く，いわゆる一筆書きの手法で文字，図形の表示が行な われる. この方式では，ちらつきなしに表示できる情報 量は電子ビームの偏向速度により制限される．表示量を 増大するために偏向速度を大きくするには，広帯域，大 電力の偏向増幅器が必要で, 電源容量も大となり装置の コストが高くなる。しかし，画質は最も良く，後述する 画素の識別が容易であるため，画面を介しての人間とコ ンピューターとの会話の手段としては最す優れている.

ラスタースキャンはテレビ受像機と同様な方法で, ビ 一ムの移動を図 $5($ b ) のように周期的に行なうむので, 画像はビームのオン・オフ制御により表示される. CRT 周辺回路は最あ簡単であり，キャラクターディスプレイ によく用いられる，ただしこの方式で，文字発生器を利 用して文字を表示する場合，文字発生器にはアクセスタ イムの短いことが要求される。乙れに適した文字発生器 としては IC の ROM がある.

モディファイドラスタースキャンは四 5 (c) に示すよ うにビームを周期的に移動させる. この方式むキャラク ターディスプレイに用いられるが，モノスコープのよう にアクセスタイムの長い文字発生器を使用する場合に用 いられる。

全面同時スキャンは画面上の像を同時にパルス的に発 光させる方式で, 後述のイリノイ型の PDP の表示がこ れに相当する．乙の型の PDP では壁電荷として情報が メモリーされており，20〜 $50 \mathrm{kHz}$ の維持電圧を全部の セルに同時に印加するととにより, 壁電荷のあるセルの

みを維持電压の 2 倍の周期で同時に発光させている，発 光の繰返しが非常に高いので，ちらつきはまったく感じ られない。

連続発光方式は，連続的に画像からの発光があるもの で，直視型蓄積管，液晶，などがこの方式に入る，との 方式ではちらつきはまったくないが，発光が連続的であ るためライトペンによる画素の識別は不可能で，画像表 示はコンピューターからの出力手段として使用される.

\section{6. コードメモリーと画像メモリーの比較}

コードメモリーと画像メモリーについての比較を, 画 像情報のメモリ一内での情報形式と表示方式に関してす でに述べたが，ここでは画素の識別に関しての比較を行 なう。

コードメモリーの場合には，戝３に示したように，メ モリーから 1 語ずつ読出して CRT に表示する. 画面上 ではちらつきなく静止像として目に写るが，ある瞬間に は，あるアドレスのメモリ一の内容で定義されている文 字やベクトルなどの画素を表示している．それゆえライ トペンで目的とする画素をピックアップした瞬間にリフ レッシュを停止し，現在，読出されているメモリーアド レスからピックアップした画素の識別を行なうことがで きる.あるいは図 6 のように，画素の先頭に識別のため のコードを入れておき，その画素の表示に先立って識別 コードを識別レジスターにセットしておけば，ライトペ ンでピックアップした場合, その識別コードからダイレ クトに画素の識別を行なうことができる.

この場合，画素の単位として，点，文字，ベクトルな ど単独でも，乙れらの集合でも，任意に選ふことができ る.

一方，画像メモリ一の場合には，もちろん直視型蓄積 管などの場合にはリフレッシュを行なってないため， ラ イトペンの使用は不可能であるが，ライトペンの使用可! 能なラスタースキャンで表示を行なう走查変換管の場合 でも，ライトペンでピックアップできるのは，画面上の $X Y$ 座標值のみであり，これからもとの画素との対応す

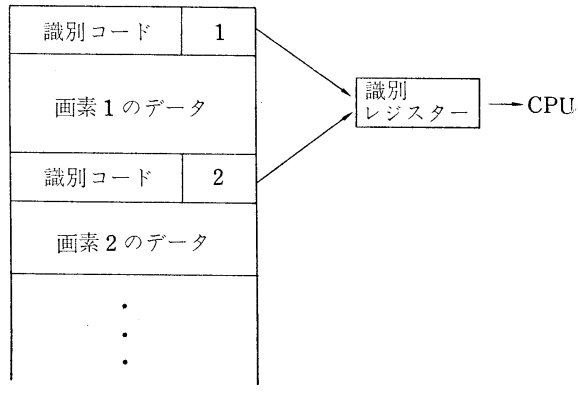

図 6 識別コードによる画素の識別 
けをソフト的に処理するのは大変めんどうである．ての ため画面上の文字や図形の識別はかなり粗いものしかで きない，たとえば文字であれば行単位程度しか実用にな らない，乙のため画像メモリ一の場合には高価なライト ペンの代りに，ジョイスティックやカーソル制御キーな どによりカーソル位置を制御し, カーソルの座標值から 画面上の $X Y$ 座標を入力する方法が之られている.

要するに, コードメモリーは表示画面を介してライト ペンにより画素の識別が容易に行なえるので, IC マス ク設計, 列車ダイヤ作成など高頻度のインタラクション を必要とするアプリケーションに適している，てのよう なアプリケーションに対しては，画像メモリーは適さな い.

画像メモリーは画素の識別が困難であるので, 出力を 主目的とするアプリケーション，たとえば科学技術計算 の結果をグラフで表示するとか, 情報検索のような場合 に適する．もちろんてのようなアプリケーションに対 し，コードメモリー型のディスプレイも利用できるが, コストの安い画像メモリー型で充分な場合が多い.

後述する新しい型の表示デバイスはすべて画像メモリ 一タイプであるため，その用途は出力を主とするあのに 限られていることに注意を要する.

\section{7. 新しいタイプの表示デバイス}

\section{1 蓄積管}

蓄積管には中間調のある像を表示できるあのと, 明暗 2 階調だけしか表示できないあのとがある. 前者の例と しては Princeton Electric 社や RCA 社の走查変換管 があり, 後者の例としては Techtronics 社の直視型蓄積 管がある。

(1) 走査変換管

図 7 亿走查変換管 (SCT) の動作原理図を示す. 走查 変換管では画像は直径 1 1. 5 in の円形ターゲットに電 荷像として蓄積される. SCT の動作には消去, 書込み,

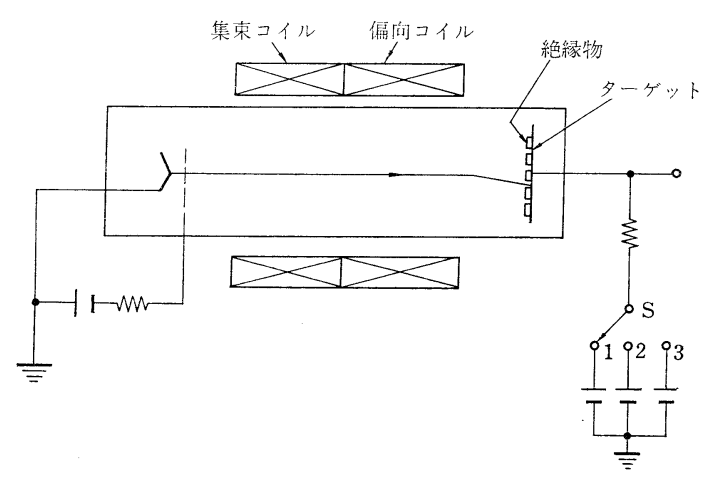

図 7 走査変換管の動作原理図
読取りの3つがある.

消去動作はターゲット上の絶縁物の表面電位を均一に し，次の書込みが行なえるようにする，消去を行なうに は，スイッチSを1に接続し，ターゲット電圧を 2 次電 子放出比 $\delta$ が 1 より小さくなる低い電圧, 約 $30 \mathrm{~V}$ 飞七 ットし, コントロールグリッド電圧を０VVし，多量の ビーム電流を照射すると絶縁物の表面電位は負方向に移 動し，０Vになって平衡する. この結果，ターゲットの 電位に対し絶縁物の表面電位は $-30 \mathrm{~V}$ になる。

次に書込みを行なうには，スイッチ $\mathrm{S} 2$ 亿切換え て，ターゲット電圧を $\delta>1$ となる約 $200 \mathrm{~V}$ にする.

入力信号によって変調を受けた電子ビームが偏向系によ って所望の位置に照射されると, 照射されたビーム量に 比例して正方向に電位変化が起とり, 中間調のある電荷 像が絶縁物上に生じる。

電荷像を読出すには，スイッチSを 3 亿切換えてター ゲット電圧を約 $20 \mathrm{~V}$ にし，コントロールグリッド電圧 を一定の負電圧にして, ビーム電流を適度にしぼり, 無 変調ビームでターゲット上を走査すると, 絶緑物の表面 電位が書込み動作によって上昇している部分は, 走査ビ 一ムが通過し，ターゲットに集められて出力として得ら れる. これを表示用の CRT にビデオ信号として入力 し, ターゲット上の電荷像を可視像に変換する. この型の蓄積管の長所としては,

(1) 中間調が得られる.

(2) 部分消去ができる.

(3) 表示を別の CRT で行なうので, 画面サイズを任 意に選ぶととができ，輝度，コントラストを高くす るととができる.

欠点としては，メモリ一用と表示用の CRT がそれぞ れ必要であるため, 次に述べる直視型蓄積管にくらべて コストが高くなることがあるが，マン・マシンインター フェイスのディスプレイとしては画像メモリーの中では

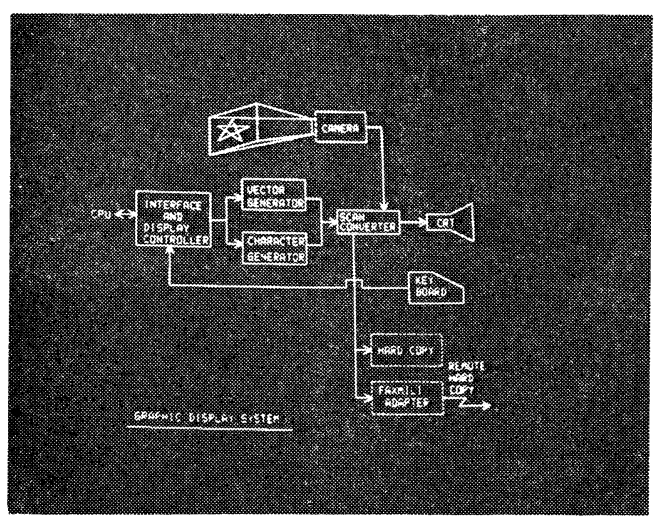

写真 1 走査変換管を用いたディスプレイの表示例 


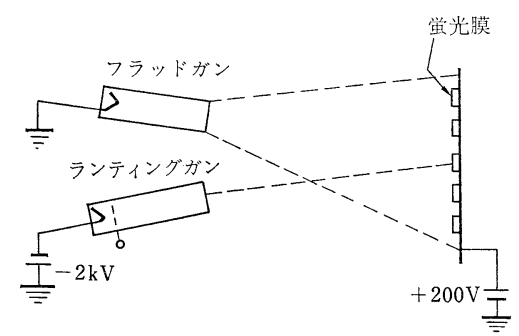

図 8 直視型蓄積管の動作原理図

最む啇していると思われる. 写真 1 は富士通で試作した 走查変換管を用いたディスプレイの表示例である.

(2) 直視型蓄積管

動作原理は，前述の走査変換管とほぼ同じであるが，

図 8 亿示すように書込み用のライティングガンと, 読出 しおよび消去用のフラッドガンとがある. CRT の内面 ガラス上に透明電極があり，その上に 2 次電子放出比の 高い螢光体が塗布されており，透明電極が集電極として 動作し，螢光膜が発光の他にメモリ一機能も兼权てい る. ライティングガンのカソード電圧は $-2 \mathrm{kV}$ になっ ているので, このビームで照射された部分は電位が上昇 し，透明電極の電位 $200 \mathrm{~V}$ まで上昇し，照射を受けない 部分はフラッドガンの電位 $0 \mathrm{~V}$ で平衡するという 2 安定 性を有する.

この型の特長は,

(1) CRT が表示と蓄積機能を兼ねているので, 周辺 回路が簡単であり，また回路は広带域のものが必要 でないのでコストが安くなる.

(2) 表示画面にちらつきがまったくない. などである。

欠点としては，メモリーと表示を1つの CRT で兼ね ているため，読出しの電子ビームのエネルギーを高くす ることができず，輝度を高くできない，画面の大きさを 自由に選べない，部分消去ができないなどがある.

部分消去ができない欠点を補なうため，Techtronics 社の T4002 ディスプレイでは, 最下行だけはメモリー 機能をなくし，通常のリフレッシュ型とし，キイボード からの入力はこの部分に表示し，入力の訂正が行なえる ようにしている.

蓄積管が PDP や液晶より優れている点は,メモリー の内容を電気的に読出すととができ，ハードコピーをと るととが容易であることである。

\section{$7.2 \mathrm{PDP}^{3) \sim 5)}$}

1966 年に Ilinoi 大学の H. G. Slottow および D. H. Bitzer が PDP に関する論文を発表してから，多くの 研究機関で PDP の開発がなされ，ようやく実用化に近 づいてきた。

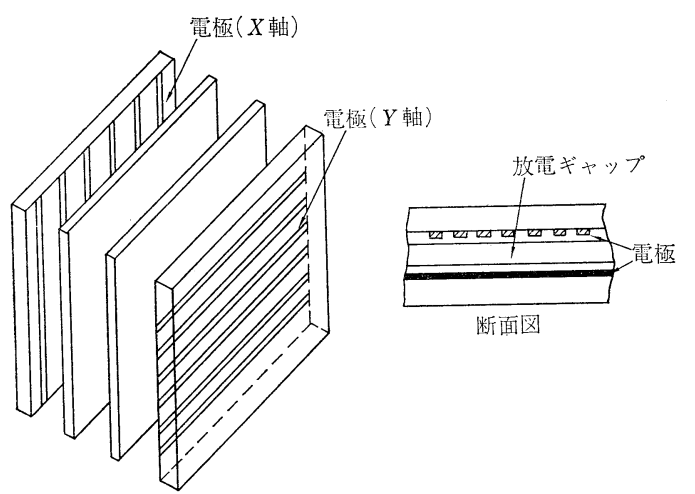

図 9 PDP の構造 (a) 放電開始時

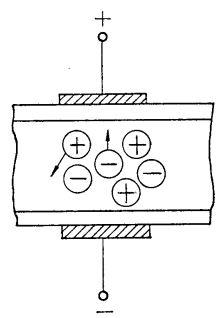

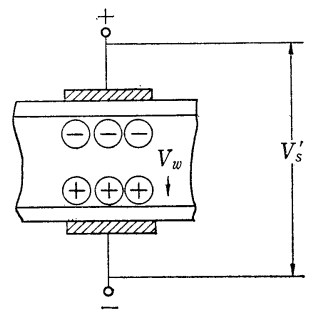

(b) 放電終了後
図 10 壁電圧の生成

PDP にはメモリー機能のあるイリノイ型と, メモリ 一機能がないバローズ型がある.とこではイリノイ型に ついて述べる.

PDP の構造には種々あるが,富士通で開発したものに ついて紹介する．図9のように厚いガラス板に電極をは りつけ，さらにその上に薄いガラス板をはりつけたもの を 2 枚準備し，薄板を内側にして電極が互いに直交する ように配置し，その間に適度の放電ギャップを設けて周 囲を封じたものである. 電極のピッチは $0.4 \sim 0.6 \mathrm{~mm}$ である。

PDP のメモリ一機能は次のような原理による．放電 セル内にかかる電圧が，放電開始電圧 $V_{f}$ を越えるとセ ル内で放電が起とり，荷電粒子を発生する．乙の荷電粒 子は電界によって図 10 のようにその電荷之逆極性の電 極に向って移動し，ガラス壁に帯電する. このようにし て生じた壁電荷はセル・壁間に電圧を発生する.これを壁 電圧 (wall voltage) 乙呼ぶ. したがって，セルに加わる 電圧 $V_{c}$ は電極に印加した電圧 $V_{s}^{\prime}$ に比例した電圧 $V_{s}$ と壁電圧 $V_{w}$ との和になる.

$$
V_{c}=V_{s}+V_{w}
$$

放電時には $V_{w}$ は $V_{s}$ と逆極性であるので， $V_{c}$ は $V_{w}$ が加わることにより小さくなり，乙の值がセルの放 電維持電圧よりも小さくなると放電は停止し, 次に放電 が起こるまで $V_{w}$ はその值が保持される. 


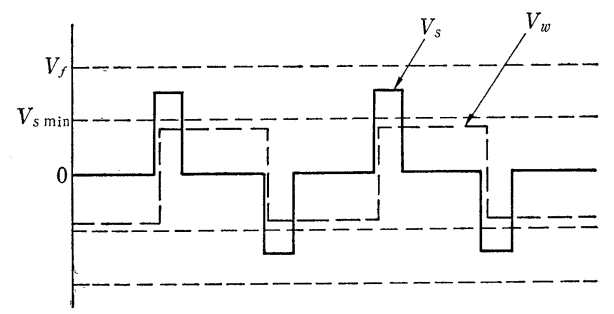

図 11 維持電压 $V_{s}$ と壁電圧 $V_{w}$ との関係

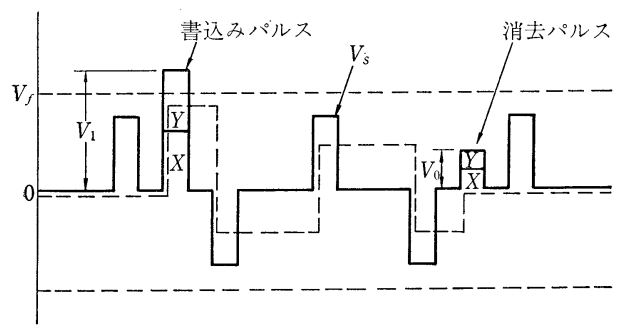

図 12 制御信号と壁電圧の関係

図签11 のように $V_{s}$ を加えると，一度放電を起とした セルでは $V_{s}$ の極性が反転したときに $V_{s}$ と $V_{w}$ が同 極性で加算されるので,

$$
\begin{aligned}
& V_{s}+V_{w}>V_{f} \\
& V_{s}<V_{f}
\end{aligned}
$$

なるよう $V_{s}$ を選べば，放電は持続し，放電を起こして ないセルはいつまで屯放電を起とさない，つまりメモリ 一されるととになる， $V s$ を維持電圧と呼ぶ.

セルの状態を消去 $(\mathrm{OFF})$ から点火 $(\mathrm{ON})$ の状態変 化させる, 換言すれば書込むには, 維持電圧の他に制御 信号が必要である. 図 12 亿制御信号の一例を示す.点 火パルスの波高 $V_{1} を$,

$$
V_{1} / 2<V_{f}<V_{1}
$$

を満足する值任選び，点火しようとするセル上を交差す る $X, Y$ 電極に，それぞれ $V_{1} / 2 ，-V_{1} / 2$ の電圧を印 加する. 交点上のセルには $V_{1}$ が印加されて放電を起て し ON になるが，他のセルには $V_{1} / 2$ しか電圧が印加 されないので放電は起こらない。

次に ON から OFF にするには図 12 に示すように $V_{0} / 2, \quad-V_{0} / 2$ なる電圧を，セルを交差する $X, Y$ 電極 にそれぞれ加えることにより $V_{\text {w }}$ がなくなるように加え ると，それ以後の $V$ s によって放電をしなくなり， OFF の状態になる.

PDP の特長としては次のあのがある.

(1) メモリ一機能がある.乙の機能によって, リフレ ッシュメモリーが不要となり, 全画面で同時に発光 させることができるので, 高輝度が得られる.

(2) 薄型である、これにより装置をコンパクトにする

第 27 巻第 11 号 (1973)

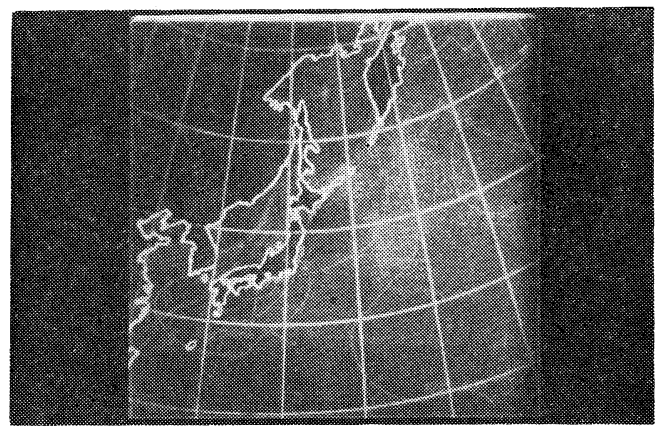

写真 2 プラズマディスプレイの表示例

(等高線は CPV からの出力, 地図はスライドからの投影像)

ことができる。

(3) 高精度表示である. 表示位置精度は電極構造で決 まるので高精度となる．とのためスライドからの光 学的情報の重畳が精度良く行なえる.

(4) 部分消去が可能である. この機能があるため, 、 ンマシン・インターフェイスとしてのディスプレイ に適している.

(5)書込み，消去速度が速い，現在， 1 ドット当りの 青込み，または消去に必要な時間は $20 \mu \mathrm{s}$ 程度で， 実用上充分な速度である。

以上の上うな特長があるが，多量の表示を必要とする 場合は電極数を多く必要とし，てのため駆動回路素子の 数が增加し，コストが高くなる欠点がある. 大面積の $\mathrm{P}$ DP の実用化は，パネル特性の均一化ととあに駆動回路 をいかに低コスト化できるかにかかっているようで，乙 れらにつき各社研究を行なっている．さらにカラー化， 多階調表示, メモリ一内容の読取り,などについてあ開 発が進められている．写真 2 は富士通で試作したプラズ マディスプレイである.

\section{3 液晶 ${ }^{6)}$}

液晶は外見的には液状で流動性があり, 光学的には固 体結晶の性質を有する有機物で, 構造的にネマチック， スメクチック，コレステリックの 3 種に分類される.

ディスプレイに使用されているのはネマチックが大部 分であるが，コレステリックのあのでカラー表示なども 試みられている。またネマチックとコレステリックを混 合するととによりメモり一機能を持たせる研究も行なわ れている.

ネマチックは特定の温度範囲で透明であるが，電圧を 加えると分子配列が変化して白濁散乱を生じる，金属反 射鏡と透明電極をつけた透明ガラス板との間飞約 10〜 $20 \mu \mathrm{m}$ 程度の厚さに液晶を封入する，金属鏡と透明電極 との間に 1 2 V $/ \mu \mathrm{m}$ 程度の電圧を加えると, その電極 に対応する部分が白濁する. 


\section{特 集 $\square$ 画像メモリー}

コレステリックは分子の配列方向が層ごとに少しずつ 回転するらせん構造をもち, そのピッチは可視光の波長 と同程度の $5,500 \AA$ 程度で，干渉のために特定波長の 光の反射が起こり着色して見える. 電界, 温度, 圧力な どでピッチが変わるため，ディスプレイでの応用が考え られる.

液晶の長所には(1)低電力, 低電圧である, (2)原理的に 任意の面積のあのが可能である, (3)薄型である, (4)外光 による発光である, (5)カラー表示が可能である, (6)低コ ストである，などがある.

現在, 液晶は各社で開発がなされているが, すでに卓 上電算機や時計などで, 7 セグメントの数字表示に応用 されている，X，Yマトリックス型のあのあ試作されて おり， $5 \times 7$ ドットマトリックスで，1行 25 文字， 1 画面 4 行の英数字を line at a time で走査し, 1 フレ 一ム $0.5 \mathrm{~Hz}$ で表示している.

上記のものはメモリー機能をあたないものであるが, ネマチック液晶とコレステリック液晶を混合することに より, 光散乱効果の蓄積とマトリックス選択を可能にし たものあある. 応答速度は通常の光散乱効果型にくらべ て約 1 桁遅いが (約 $200 \mathrm{~ms}$ ), 閾值がシャープで, マト リックス選択表示に拈けるコントラストを向上させてお り，蓄積時間は数日以上である.

液晶は応答速度が遅いため, それ自体にメモリ一機能 を持たせることができたとしても，応答速度が改善され ない限りその応用分野は限定され, 主として表示文字数 の少ない文字ディスプレイとして利用されると思われ る.

\section{4 カソードクロミック管}

物質に光をあてると変色し，光を遮断すると元に戻る 現象をフォトクロミズムといい，電子線で色の変わるの をカソードクロミズム現象と呼ぶ.

カソードクロミック管の構造は通常のテレビ用 CRT とほぼ同じであるが， CRT 面の螢光体の代わりにン一 ダライトを使用し，背面からの投射光を通過させるため
に, アルミニウムメタルバックやグラファイトコーティ ングの代りに透明導電膜を塗布している.

白色のソーダライトに電子ビームを当てると, そてが 変化し特定の波長の光を吸収する現象を利用する.ソー ダライト自身は発光しないが， CRT の背面から白色光 で照らすと，電子ビームが当った部分は特定の波長の光 を吸収するので，CRT 面上に電子ビームの軌跡が像と して表示される.

カソードクロミック管の特徽としては,

(1) 画像を $\min$ のオーダーで蓄積する.

(2) 中間調表示が可能.

(3) 高分解能である.

(4) 製造工程がテレビ用 CRT とほとんど同じである ので低コストである.

などがある、電話回線などを利用した画像情報サービス などに適していると思われる。

\section{8. むす び}

以上, ディスプレイ方式とメモリーの特徴につき述 べ，最近開発が行なわれている表示デバイスにつき紹介 した.

低コストディスプレイの開発には，低コストでメモ リー機能があり, 駆動電圧が低く, 高輝度の表示デバイ スの開発が強く望まれる.

\section{〔参考文 献}

1) C. Machover: Computer graphics terminals-A backward look, SJCC (1972)

2) T. G. Hagan, et al: The future of computer graphics, SJCC (1972)

3）山本祐二: プラズマディスプレイパネルの特性および駆動方法, 電子科学, 12 (1.972)

4) 中山典彦：プラス゚マディスプレイについて，昭46年関西支部連大

5) H. G. Slottow: The plasma display panel—principles and prospect, IEEE Conf. on Display Devices (Dec. 1970)

6) 三輪博秀: ディスプレイデバイスの現状と将来, テレビ誌，25, 9 (1971)

7) T. Ohtsuka: Liquid Cristal Matrix Display, Japan. J. Appl. Phys., 12, 3, Mar. (1973)

8) 三輸博秀ほ加: 液晶表装置の実用化について, 第 3 回画像工学コ ンファレンス, 3-4 (Nov. 1972) 